conducted in Indonesian adults with severe cholera confirmed these findings and showed a 19\% reduction in stool output with oral rehydration solution containing glucose and glycine compared with the standard oral rehydration solution. ${ }^{6}$ On the other hand, results from six studies in children under 3 years with acute diarrhoea, including diarrhoea associated with rotavirus, showed that the addition of glycine and, in some studies, glycyl-glycine to glucose oral rehydration solution had no consistent beneficial effect on the stool output, intake of oral rehydration solution, or duration of diarrhoea. ${ }^{62021}$

Our results support the concept that absorption of sodium and water can be increased significantly by adding an amino acid to the oral rehydration solution. Before a new formula for oral rehydration solution is proposed, however, several studies should be conducted to determine the efficacy of the new solution in treating diarrhoea of various origins in young children; the optimal osmolality of the solution and the optimal amino acid concentration; and whether other amino acids might be even more efficacious than alanine in promoting absorption of salts and water.

This research was supported by a grant from the Programme for Control of Diarrhoeal Diseases, World Health Organisation, Geneva. We thank Dr Dilip Mahalanabis for proposing this study and his help in statistical analysis and preparing the manuscript; Dr Roger Eeckels for his support and his critical review of the manuscript; the staff of the clinical research centre for their help; and $\mathrm{Mr}$ Meer Mohammed Ramzan Ali and Ms Loretta Saldanha for secretarial help.

1 Anonymous. Oral glucose/electrolyte therapy for acute diarrhoea [Editorial] Lancet 1975;i:79-80.
Anonymous. Oral therapy for acute diarrhoea [Editorial]. Lancet 1981 ;ii: $615-7$

The time has come [Editorial]. Lancet 1983;ii:259.

4 Sack DA, Chowdhury AMAK, Eusof A, et al. Oral hydration in rotavirus diarrhoea: a double blind comparison of sucrose with glucose electrolyte solution. Lancet 1978;ii:280-3.

5 Pierce NF, Sack RB, Mitra RC, et al. Replacement of water and electrolyte losses in cholera by an oral glucose electrolyte solution. Ann Intern Med 1969;70:1173-81

6 World Health Organisation. Sixth programme report 1986-1987: programme for control of diarrhoeal disease. Geneva: WHO, 1988:42-6. (WHO/CDD/88.28.)

Patra FC, Mahalanabis D, Jalan KN, Sen A, Baneriee P. In search of a super solution: controlled trial of glycine-glucose oral rehydration solution in infantile diarrhoea. Acta Paediatr Scand 1984;73:18-21.

8 Nalin DR, Cash RA, Rahman M, Yunus MD. Effect of glycine and glucose on odium and water absorption in patients with cholera. Gut 1970;11:768-72.

Parr FC, Mahalabis D, Jalan KN, Sen A, Ban . solution superior to glucose
Dis Child 1982:57:910-2.

10 Molla AM, Ahmed SM, Greenough WB. Rice-based oral rehydration solution decreases the stool volume in acute diarrhoea. Bull WHO 1985;63:751-6.

11 Mahalanabis D. Development of an improved formulation of oral rehydration salts $(O R S)$ with antidiarrhoeal and nutritional properties: a "super ORS." Geneva: WHO, 1985:7-8. (WHO. CDD/DDM/85.3.)

2 Hellier MD, Thirumalai $C$, Holdsworth CD. The effect of amino acids and dipeptides on sodium and water absorption in man. Gut 1973;14:41-5.

13 Reynolds JEF, ed. Martindale; the extra pharmacopoeia. 28th ed. London: Pharmaceutical Press, 1982:48.

14 Genuth SM. Effects of oral alanine administration in fasting obese subjects. Metabolism 1973;22:927-37.

15 Rhoads JM, Macleod RJ, Hamilton JR. Alanine enhances jejunal sodium absorption in the presence of glucose: studies in piglet viral diarrhea. Pediatr Res 1986;20:879-83.

16 World Health Organiation. Manual for laboratory investigations of acute enteric infections. Revised ed. Geneva: WHO, 1987:42-58. (WHO/CDD/83.3.)

17 Nalin DR, Cash RA, Islam R, Molla AM, Phillips RA. Oral maintenance therapy for cholera in adults. Lancet 1968 ;ii:370-2.

18 Sack RB, Cassels J, Mitra RC, et al. The use of oral replacement solutions in the treatment of cholera and other severe diarrhoeal disorders. Bull WHO 1970;43:351-60.

19 Palmer DL, Koster FT, Islam AFMR, Rahman ASMM, Sack RB. Comparison of sucrose and glucose in the oral electrolyte therapy of cholera an other severe diarrheas. N Engl I Med 1977;297:1107-9.

20 Santosham M, Burns BA, Reid R, et al. Glycine-based oral rehydration solution: reassessment of safety and efficacy. $\mathcal{F}$ Pediatr 1986;109:795-801.

21 Vesikari T, Isolauri E. Glycine supplemented oral rehydration solutions for diarrhoea. Arch Dis Child 1986;61:372-6.

(Accepted I March 1989)

\title{
Paradoxical survival of elderly men with high blood pressure
}

\section{Robert D Langer, Theodore G Ganiats, Elizabeth Barrett-Connor}

Department of Community and Family Medicine, University of California, San Diego, California 92093, United States Robert D Langer, $\mathrm{MD}$, assistant adjunct professor Theodore G Ganiats, MD, associate clinical professor Elizabeth Barrett-Connor, $\mathrm{MD}$, professor

Correspondence to: $\mathrm{Dr}$ Langer.

Br.Hed 7 1989:298:1356-8
A recent study in Finland found a paradoxical graded positive association between blood pressure and survival in people aged 85 and over. ${ }^{1}$ Other studies have shown a lack of association between hypertension and mortality in elderly people but not this unexpected advantage in terms of survival, possibly because they had too few very old subjects. ${ }^{2-4}$ We tested this relation in another cohort.

\section{Patients, methods, and results}

In 1972-4 all adults living in a predominantly white, upper middle class retirement community were invited to a cardiovascular screening programme in which blood pressure was measured with a mercury sphygmomanometer after the subject had been seated for five minutes; $4382(82 \%)$ participated. All 2270 participants aged $\geqslant 65$ at the start of the study were evaluated. Vital states after 10 years was known for 2268 subjects (99.9\%); death certificates were obtained for all people who had died. Deaths were coded with the International Classification of Disease, ninth revision; codes 400-438 were taken to represent cardiovascular disease.

After 10 years there had been 448 deaths in 1159 men and 254 deaths in 1109 women, giving an overall mortality of $31 \%$. Cardiovascular disease caused 320 $(71 \%)$ deaths in men and $149(59 \%)$ in women. Subjects were divided into three age groups and four categories each of diastolic and systolic blood pressure based on distribution. Relative survival by category of blood pressure was calculated with Kaplan-Meier techniques for all cause and cardiovascular mortality. Results were tested with the $\chi^{2}$ test for trend. Because of the difference in cardiovascular mortality between the sexes we analysed these effects separately for men and women.

The table shows the results. In men aged $\geqslant 75$ low diastolic blood pressure was associated with the greatest all cause $(p=0.04)$ and cardiovascular $(p=0.02)$ mortality and higher diastolic blood pressure predicted survival. By contrast, in younger men and in women of all age groups the usual positive association between blood pressure and death due to all causes or cardiovascular disease was found.

\section{Comment}

Our analysis confirms a paradoxical graded survival advantage in men aged $\geqslant 75$ with increasing diastolic blood pressure for both all cause and cardiovascular mortality. This relation was not seen in women or younger men. The relation between systolic blood pressure and survival was not conclusive.

The previous study of this relation from Finland looked at mainly women (82\%) and results were for both sexes combined. ${ }^{1}$ In the present study, which included similar numbers of men and women, we were unable to find a positive relation between blood pressure and survival in women. Our population was younger than the Finnish cohort: in the $\geqslant 75$ age group the mean age was $78 \cdot 1$ years $(78 \cdot 0$ for men and $78 \cdot 3$ for women), whereas the mean age in the Finnish cohort was 88.4 years. The strong inverse relation seen in the oldest men between diastolic blood pressure and cardiovascular death and the high proportion of deaths 


\begin{tabular}{|c|c|c|c|c|c|c|c|c|c|c|c|}
\hline \multirow[b]{2}{*}{ Age (years) } & \multirow[b]{2}{*}{ No who died } & \multicolumn{5}{|c|}{ Diastolic blood pressure $(\mathrm{mm} \mathrm{Hg})$} & \multicolumn{5}{|c|}{ Systolic blood pressure $(\mathrm{mm} \mathrm{Hg})$} \\
\hline & & $\overline{<75}$ & $75-84$ & $85-94$ & $\geqslant 95$ & p Value ${ }^{\star}$ & $<130$ & $130-149$ & $150-169$ & $\geqslant 170$ & p Value \\
\hline \multicolumn{12}{|c|}{ Men } \\
\hline \multicolumn{12}{|l|}{ All cause: } \\
\hline 65 & $126 / 496$ & 0.96 & 0.61 & $1 \cdot 30$ & 1.50 & 0.01 & 0.50 & 0.87 & $1 \cdot 31$ & $1 \cdot 71$ & $<0.01$ \\
\hline 70 & $172 / 417$ & 0.78 & 0.95 & $1 \cdot 28$ & 1.01 & $0 \cdot 10$ & 0.77 & 0.94 & $1 \cdot 10$ & $1 \cdot 20$ & 0.05 \\
\hline$\geqslant 75$ & $150 / 246$ & $1 \cdot 29$ & $1 \cdot 02$ & 0.74 & 0.92 & 0.04 & $1 \cdot 18$ & 0.95 & 0.97 & 0.98 & 0.58 \\
\hline \multicolumn{12}{|c|}{ Cardiovascular: } \\
\hline 65 & $78 / 496$ & 0.90 & 0.49 & 1.45 & 1.62 & $<0.01$ & 0.43 & 0.84 & $1 \cdot 18$ & $2 \cdot 23$ & $<0.01$ \\
\hline 70 & $124 / 417$ & 0.72 & 0.92 & 1.33 & 1.09 & 0.05 & 0.63 & 0.82 & $1 \cdot 29$ & $1 \cdot 25$ & 0.01 \\
\hline$\geqslant 75$ & $118 / 246$ & $1 \cdot 36$ & 1.05 & 0.72 & 0.81 & 0.02 & $1 \cdot 28$ & 0.91 & 0.96 & 0.97 & 0.46 \\
\hline \multicolumn{12}{|c|}{ Women } \\
\hline \multicolumn{12}{|l|}{ All cause: } \\
\hline 65 & $83 / 515$ & 0.83 & 0.82 & $1 \cdot 36$ & $1 \cdot 19$ & $0 \cdot 10$ & 0.96 & 0.76 & 1.46 & $1 \cdot 22$ & $0 \cdot 19$ \\
\hline 70 & $84 / 386$ & 1.06 & 1.01 & 0.82 & $1 \cdot 27$ & 0.99 & 0.59 & 0.88 & $1 \cdot 23$ & $1 \cdot 37$ & 0.01 \\
\hline$\geqslant 75$ & $87 / 208$ & 0.79 & 0.95 & $1 \cdot 22$ & $1 \cdot 14$ & $0 \cdot 19$ & 0.74 & $0 \cdot 76$ & $1 \cdot 13$ & $1 \cdot 21$ & 0.08 \\
\hline \multicolumn{12}{|c|}{ Cardiovascular: } \\
\hline 65 & $42 / 515$ & 0.58 & 0.68 & 1.54 & $1 \cdot 76$ & 0.01 & 0.68 & $0 \cdot 78$ & $1 \cdot 77$ & 1.44 & 0.03 \\
\hline 70 & $43 / 386$ & 0.69 & $1 \cdot 25$ & 0.92 & 1.06 & 0.70 & 0.58 & 0.79 & $1 \cdot 37$ & $1 \cdot 34$ & 0.05 \\
\hline$\geqslant 75$ & $64 / 208$ & 0.89 & 0.89 & $1 \cdot 13$ & $1 \cdot 24$ & 0.33 & 0.88 & $0 \cdot 71$ & 0.97 & $1 \cdot 35$ & 0.09 \\
\hline
\end{tabular}

${ }^{\star} \chi^{2}$ Test for trend, $1 \mathrm{df}$.

from cardiovascular events suggest that much of the survival benefit was due to lower cardiovascular mortality. Our failure to find this paradoxical relation in women could be explained by a later onset of cardiovascular disease in women. ${ }^{5}$ The higher incidence and earlier onset of cardiovascular disease in Finland compared with the United States could also account for these contrasting results.

The positive relation between survival and diastolic blood pressure shown in men aged $\geqslant 75$ directly contrasts with the continuous negative relation between diastolic blood pressure and survival reported in younger people and in younger men and all women in our cohort. These results await explanation, and suggest a need to re-evaluate strategies for managing high blood pressure in very old patients.

This study was supported by grant NIADDKD AM31801.

1 Mattilea K, Haavisto M, Rajala S, Heikinhiemo R. Blood pressure and five year survival in the very old. BrMed f 1988;296:887-9.

2 Luepker RV. Coronary risk factor modification in the elderly coronary patient. Geriatric Cardiovascular Medicine 1988;1:115-21.

3 Kirkendall WM. Treatment of hypertension in the elderly. Am 7 Cardiol 1986; 57:63-68C.

4 Kannel WB. Prevalence, incidence, and hazards of hypertension in the elderly. Am Heart 7 1986;112:1362-3.

5 Thom TJ. Cardiovascular disease mortality among United States women. In: Eaker ED, Packard B, Wenger NK, Clarkson TB, Tyroler HA, eds. Coronary heart disease in women. New York: Haymarket Doyma, 1987:33-41.

(Accepted 3 March 1989)

\section{Insulin requirements of diabetic women who breast feed}

\author{
H Alban Davies, J D A Clark, K J Dalton, \\ O M Edwards
}

Department of Medicine, Addenbrooke's Hospital, Cambridge CB2 2QQ H Alban Davies, MRCP, senior registrar in medicine J D A Clark, MRCP, research fellow

O M Edwards, FRCP, consultant physician

Perinatal Research Unit, Rosie Maternity Hospital, University of Cambridge, Cambridge CB2 $2 Q Q$ $\mathrm{K} J$ Dalton, MRCOG, honorary consultant obstetrician

Correspondence to: $\mathrm{Dr}$ H Alban Davies, West Hill Hospital, Dartford, Kent DA1 2HF.

BrMed f 1989;298:1357-8
Diabetic women are advised to resume the dose of insulin that they took before pregnancy within one week after giving birth, whether they intend to breast feed or not, ${ }^{1}$ despite reports that breast feeding decreases insulin requirements. ${ }^{2}$ This ambivalence is due to lack of information about the effect of breast feeding on insulin requirements and the belief that it is difficult for mothers with diabetes to breast feed. ${ }^{23} \mathrm{We}$ describe the changes in insulin dose and diabetic control in diabetic women up to six weeks after delivery.

\section{Patients, methods, and results}

We studied 24 consecutive pregnancies in 21 insulin dependent diabetic women (three women had a second pregnancy during the study period). Breast feeding was established after 18 pregnancies and continued in 16 cases until the visit to the postnatal clinic six weeks later. Patients were initially advised to take the same dose of insulin as that taken before pregnancy. Five of those breast feeding, however, had moderately severe hypoglycaemic reactions while in the ward. Subsequently, insulin doses were reduced below the prepregnancy dose immediately after delivery and then adjusted according to blood glucose concentrations. The reduction in the insulin dose one week after delivery was 11.6 units ( $95 \%$ confidence interval 8.9 to 14.3 units, $p<0.001)$ in the women who were breast feeding compared with $5 \cdot 2$ units $(1 \cdot 1$ to $9 \cdot 3$ units, NS) in those who were bottle feeding. The table shows the doses post partum and at the visit to the postnatal clinic. The reduction in the insulin dose post partum, but not that at the postnatal clinic, was significantly greater in those who were breast feeding than in those who were bottle feeding $(p=0.03)$. Carbohydrate intake was not assessed accurately, but 10 of those breast feeding and one who bottle fed reported an increased intake after delivery.

The average reduction in the insulin dose post partum was 11.1 units $(8.3$ to 13.9 units) in the 18 women who delivered vaginally and 6.8 units $(1 \cdot 7$ to 11.9 units) in the six who were delivered by caesarean section (intergroup difference, NS).

\section{Comment}

After delivery breast feeding women needed to reduce their insulin dose by $27 \%$ of their prepregnancy

Mean (SD) glycated haemoglobin and blood glucose concentrations and insulin doses during pregnancy, one week post partum, and at visit to postnatal clinic

\begin{tabular}{|c|c|c|c|c|c|c|c|}
\hline & \multicolumn{2}{|c|}{ Glycated haemoglobin (\%) } & \multirow{2}{*}{$\begin{array}{l}\text { Blood glucose } \\
\text { post partum } \\
(\mathrm{mmol} / \mathrm{l})\end{array}$} & \multicolumn{4}{|c|}{ Insulin dose (units) } \\
\hline & $\begin{array}{l}\text { At end of } \\
\text { pregnancy }\end{array}$ & $\begin{array}{l}\text { At postnatal } \\
\text { clinic }\end{array}$ & & $\begin{array}{l}\text { In early } \\
\text { pregnancy }\end{array}$ & $\begin{array}{l}\text { At end of } \\
\text { pregnancy }\end{array}$ & Post partum & $\begin{array}{l}\text { At postnatal } \\
\text { clinic }\end{array}$ \\
\hline $\begin{array}{l}\text { Breast feeding women } \\
\text { Bottle feeding women }\end{array}$ & $\begin{array}{l}6 \cdot 3(0 \cdot 7) \\
5 \cdot 9(0 \cdot 5)\end{array}$ & $\begin{array}{l}7 \cdot 6(1 \cdot 5) \\
6 \cdot 9(0 \cdot 3)\end{array}$ & $\begin{array}{l}6 \cdot 5(1 \cdot 8) \\
8 \cdot 8(3 \cdot 4)\end{array}$ & $\begin{array}{l}44(15) \\
46(10)\end{array}$ & $\begin{array}{l}96(36) \\
72(8)\end{array}$ & $\begin{array}{l}33(13) \\
41(10)\end{array}$ & $\begin{array}{l}37(13) \\
46(12)\end{array}$ \\
\hline
\end{tabular}

